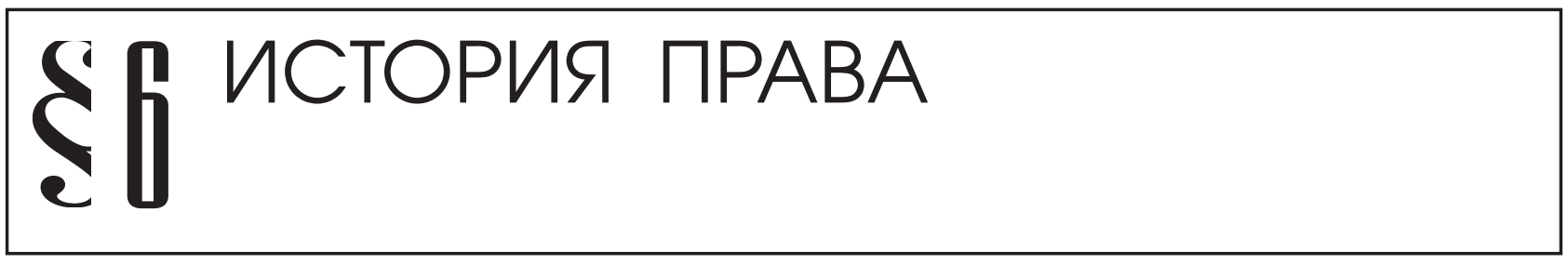

Кравец И.А.

\title{
О ПОНИМАНИИ И СУДЬБЕ МОНАРХИЧЕСКОГО БИКАМЕРАЛИЗМА В РОССИИ В НАЧАЛЕ ХХ ВЕКА
}

Аннотация: B статье рассматриваются теоретические основы и исторические аспекты российского бикамерализма в начале ХХ века. Раскрывается роль Государственной Думы и Государственного Совета в двухпалатной системе, оценка бикамерализма русскими конституционалистами. В работе автор исследует вопрос о принциипах организации и взаимодействии Государственной Думьл и Государственного Совета как двухпалатной законодательной системы. Учитываются исторические и политические условия реформирования государственного строя России, повлиявиие на формирование первой двухпалатной системы в Российском государстве. В статье обсуждаются мнения государственных реформаторов, высказанные на совещании в Царском селе (14 и 16 февраля 1906 года), о принципе равноправия палат, роли и значении бикамерализма для Российского государства и института монархии. На основе сравнительно-правового и конкретно-исторического методов анализа в статье освещаются основные способы формирования палат парламента (особенно верхних палат) в конституциионных государствах в начале ХХ века и специфика российского монархического бикамерализма. Автор приходит к выводам, что на судьбу российского монархического бикамерализма повлияло отрицательное отношение либералов и прогрессивной общественности к порядку формирования Государственного совета как верхней палаты. Политические взгляды кадетов на верхнюю палату способствовали формированию негативного общественного мнения в стране о факте существования Государственного совета. Поэтому именно в Государственной думе представители либеральных и сочуиалистических партий видели орган народного представительства и отказывались признать представительный характер за Государственным советом.Политическая судьба монархического бикамерализма - первого в конституционной истории России была значимой как конституциионный опыт взаимодействия законодательных палат на общенациональном уровне, однако имела плачевное завершение и не оказалась востребованной для совершенствования государственного строя.

Review: The article is devoted to the theoretical grounds and historical aspects of the Russian bicameralism at the beginning of the $20^{\text {th }}$ century. The author describes the role of the State Duma and State Council in a two-chamber system of government and evaluation of bicameralism by Russian constitutionalists. In his research the author studies the principles of organization and interaction of the State Duma and State Council as the two chambers of the legislative system. The author takes into account historical and political conditions of reformation of the state structure in Russia that influenced the creation of the first two-chamber system of the Russian government. The author also discusses opinions of state reformers expressed at the meeting in the Tsarskoye Selo held on February 14 and 16 in 1906 regarding the principle of equal rights of the chambers and the role and importance of bicameralism for the Russian state and institution of monarchy. Based on the comparative legal and particular historical methods of analysis the author describes the main methods of forming the parliament chambers (especially the upper chambers) in the constitutional states the beginning of the 20th century and specifics of the Russian monarchic bicameralism. The author comes to the conclusions that the Russian monarchic bicameralism was influenced by the negative attitude of liberals and progressive community towards establishing the State Council as the upper chamber. Political views of Kadets on the upper chamber created the negative public opinion on the State Council in Russia. This is the reason why the representatives of the liberal and socialist parties saw the State Duma as the body of the representation of people and therefore refused to recognize the representative nature of the State Council. Political destiny of the monarchic bicameralism s the first bicameralism in Russia was important both as the constitutional experience of interaction between legislative chambers at the overall national level but nevertheless failed to be demanded for improvement of the state structure. 
Ключевые слова: Парламент, бикамерализм, политическая ответственность, Государственная Дума, Государственный Совет, равноправие палат, конституционная монархия, монархический конституциионализм, реформирование государственного строя, законодательный прочесс.

Keywords: Parliament, bicameralism, political responsibility, State Duma, State Council, equal rights of chambers, constitutional monarchy, monarchic bicameralism, reformation of the state structure, law-making process.

B современных исследованиях по конституционной юриспруденции бикамеральная структура парламента признаётся одним из принципов организации современных парламентских учреждений, а также принципом законотворческой деятельности парламента. Бикамерализм имеет как сравнительно-правовое, так и конкретноисторическое измерение применительно в современным государствам в целом и к России в особенности ${ }^{1}$. Современные исследования роли верхней палаты в период конституционного эксперимента 1906-19017 гг. свидетельствуют о важном значении истории государственных учреждений России, имевших представительные начала в организации и деятельности ${ }^{2}$. Анализ теоретических основ и исторических аспектов российского бикамерализма в начале XX века позволяет выявить намерения реформаторов государственного строя и проблему неприятия результатов реформы представителями конституционно-правовой мысли, конституционалистами, партией конституционных демократов. Негативная оценка возникшего в результате реформы монархического бикамерализма повлияла на возможность вхождения кадетов в состав Совета Министров, деятельность Государственной Думы и Государственного Совета в двухпалатной системе.

Переход России от абсолютизма к конституционной форме правления в начале $\mathrm{XX}$ века был связан с появлением нового государственного учреждения парламента - в качестве органа народного представительства. Российский парламент состоял из двух палат - Государственной думы, название которой было заимствовано из плана государственного преобразования М.М. Сперанского, и Государственно-

\footnotetext{
${ }^{1}$ Булаков О.Н. Бикамеральная структура парламента (практика и проблемы законотворчества) // Конституционное и муниципальное право. 2006. № 9. С. 9-12.

${ }^{2}$ Юртаева Е.А. Государственный совет в России. 19061917 гг. М.: Едиториал УРСС, 2011; Юртаева Е.А. Государственный Совет в России (1906-1917 гг.) // Государство и право. 1996. Т. 70. № 4. С. 145-152.
}

го совета, в дореформенный период являвшегося законосовещательным органом, а в ходе государственной реформы преобразованного в верхнюю палату. При этом к российской двухпалатной структуре законодательного органа термин «парламент», как он понимался в западноевропейских странах при переходе в XX век, применим лишь условно. Законодательные палаты в России обладали легально ограниченным характером полномочий, не имели возможности привлекать к конституционной ответственности министров за незаконные действия. К тому же сам термин “парламент" не использовался для характеристики Государственной думы и Государственного совета ни в законодательных актах начала XX века, ни в наказах палат, ни в повседневной практике их деятельности.

Учреждение Государственной думы и реформирование Государственного совета было значительным шагом вперед в развитии начал представительного правления в России. Появление общенационального представительного органа стало символом конституции.

На рубеже столетий выборными органами в Российском государстве были органы земского и городского самоуправления. В период государственной реформы 1904-1906 гг. в бюрократических кругах рассматривались альтернативные проекты создания представительного учреждения. Тем не менее, попытка возродить Земский Собор отвергалась не только правительством, но и политическими программами либеральных политических партий. Земский Собор, сыгравший огромную роль в воцарении дома Романовых на российском престоле, в XX веке не мог выполнять выработанные в новое время функции представительного учреждения. Во-первых, в период своего существования он не являлся постоянно действующим учреждением, а именно это требование и являлось первым признаком парламента. Поэтому подобная форма государственного учреждения не могла обеспечить полноценного участия народного представительства в решении важнейших вопросов государ- 


\section{Политика и общество 9 (117) • 2014}

ственной жизни. Во-вторых, Земский Собор носил сословный характер. Между тем против сословного ценза, за введение всеобщего избирательного права выступали не только левые либералы - кадеты, но и правые - октябристы. В-третьих, голос Земского Собора был совещательным, этот орган не обладал ни законодательными, ни финансовыми, ни контрольными полномочиями. В литературе отсутствовала единая точка зрения на характер русских Земских Соборов. Различные авторы неоднозначно отвечали на вопросы, ограничивало ли это учреждение власть монарха или дополняло и содействовало созданию сильной государственной власти, было ли оно совещательным или фактически пользовалось учредительной властью. Тем не менее, следует учитывать, что существовало огромное различие между ним и его западноевропейскими аналогами, с одной стороны, и современным парламентом, с другой ${ }^{3}$.

В ходе создания законодательных палат необходимо было решить две проблемы: во-первых, определить, будет ли правовой статус Государственной думы и Государственного совета основываться на принципе равенства и в какой мере его распространять на взаимоотношения палат; во-вторых, закрепить принципы формирования Государственного совета и его права по отношению к Думе. Правовой статус палат и порядок формирования Государственного совета были взаимосвязанными явлениями, и это отчетливо понималось в процессе реформирования государственного строя.

Правовое положение Государственной думы и Государственного совета регламентировалось правовыми актами двоякого рода. Во-первых, Основными законами 23 апреля 1906 г., которые могут быть отнесены к разряду конституций. Во-вторых, специальными правовыми актами, носящими характер статутов - Учреждением Государственной думы от 20 февраля 1906 г. и Учреждением Государственного совета от 23 апреля 1906 г.

Российская революция 1905-1907 гг. была разновидностью социального конфликта, следствием самобытного пути развития российского общества. В ходе ее социальное недовольство различных классов проявилось в разнообразных подчас экстраординарных формах. Конституционная монархия в

\footnotetext{
${ }^{3}$ Покровский М.Н. Земский собор и парламент // Конституционное государство. Сб. статей. СПб., 1905. С.431-459.
}

России появилась не в результате принципиального соглашения между властью и либеральной общественностью, а вследствие беспорядков, вызванных социальным конфликтом. Поэтому новая государственная система несла внутри себя пятна такого сложного и насильственного конфликта, каким была российская революция ${ }^{4}$.

В России начала XX века легальное оформление системы монархического конституционализма было осуществлено целым рядом правовых актов, важнейшимизкоторых сталаперваяроссийская конституция - Основные законы 23 апреля 1906 года. Впервые термин “конституция” стал использоваться применительно к новой редакции Основных законов в статьях либеральных государствоведов и конституционалистов в 1906-1908 гг., а также в курсах по государственному и конституционному праву и стал общепринятым впоследствии в среде кадетов и октябристов. Следовательно, в российском государствоведении думского периода термин “конституция" применялся довольно широко для характеристики изданных в 1906 году Основных законов. Примечательно, что одни и те же конституционалисты (например, В.М. Гессен, Н.И. Лазаревский), применяя догматический подход к новым нормам права, говорили о появлении в России конституции 5 . В то же время как кадеты, они отдавали дань партийной критике Основных законов, что в дальнейшем послужило основанием для многих исследователей считать их мнимой конституцией (лжеконституцией).

Революционный процесс был неразрывно связан с реформаторскими устремлениями таких либерально настроенных бюрократов, как Витте, а затем и Столыпин. При этом важным для понимания итогов преобразовательной деятельности является не только осознание того факта, что переход к конституции не был мирным, а сопровождался социальным взрывом, но и выяснению следующего обстоятельства: почему в России, несмотря на высокий теоретический уровень знаний конституционалистов и либеральных государствоведов, стал возможен только октроированный тип конституци-

\footnotetext{
${ }^{4}$ Hosking G.A. Russian constitutional experiment: Government and Duma, 1907-1914. Cambridge, 1973. P.3.

5 Гессен В.М. Основы конституционного права. Изд. 2-е. Петроград, 1918; Лазаревский Н.И. Лекции по русскому государственному праву. Т.1. СПб., 1908. С.111-112.
} 
онализма в политических реалиях думского периода. Ответ на этот вопрос служит доказательством общего правила, что и форма правления, и тип учреждаемой конституции не может быть результатом произвольного выбора, как реформаторов, так и представителей либеральной оппозиции; они детерминируются целой гаммой обстоятельств политического и правового характера, которые в совокупности образуют в каждой стране уникальную констелляцию исторических условий перехода от абсолютизма к конституционализму.

На Царскосельских совещаниях в феврале 1906 г. по выработке Учреждений Государственной думы и Государственного совета возникли разногласия по поводу принципа равноправия палат. Проблема двухпалатной структуры обсуждалась дважды: на заседаниях 14 и 16 февраля. Еще до момента первого заседания взгляды участников разделились следующим образом. 25 членов совещаний стояли за равноправие палат, а именно за тот важнейший принцип двухпалатной системы, что только одобренные Государственным советом законопроекты, принятые до этого Думой, передаются монарху на утверждение. По мнению 2 членов совещаний соответствующую статью следовало редактировать по другому. Законопроекты, одобренные Государственной думой, но не принятые Государственным советом, возвращаются для нового рассмотрения в Думу. Те из них, которые будут вновь приняты Думой простым большинством голосов, могут быть затем отклонены Государственным советом. Если же в пользу законопроекта при вторичном обсуждении его Думой выскажется не менее $2 / 3$ общего числа данного состава членов Думы, то законопроект, хотя бы он и не был принят Государственным советом, представляется монарху ${ }^{6}$.

По свидетельству А.Д. Оболенского 2 (оберпрокурора $)^{7}$ эта редакция, к которой он присоединился, была первоначально предложена Н.Н. Кут-

\footnotetext{
${ }^{6}$ Царскосельские совещания. Протоколы секретного совещания в феврале 1906 года под председательством бывшего императора по выработке Учреждений Государственной думы и Государственного совета. (14 и 16 февраля 1906 г.) // Былое.1917. № 5-6. С.301-302.

7 Членами Царскосельских совещаний были два князя Оболенских, которые в протоколах значились под номерами 1 и 2: А.Д. Оболенский 1 - член Государственного совета, А.Д. Оболенский 2 - обер-прокурор.
}

лером. В пользу этого предложения колебался и граф Д.М. Сольский.

Оболенский 2 считал необходимой именно эту редакцию (данную точку зрения он отстаивал 14 февраля) вследствие того, что “обсуждаемое преобразование государственного совета явится сюрпризом" для либеральной общественности. “Ждали только думу. Вдруг, кроме думы, - говорил он, - является с решительным голосом также государственный совет, который может не допустить того, что уже принято думою"8. Следовательно, в ходе обсуждения отдельными членами совещания ясно осознавалось, что учреждение Государственного совета в качестве верхней палаты вызовет недовольство либеральных партий и может подорвать доверие между правительством и обществом. Поэтому отстаиваемое Оболенским 2 нововведение должно было смягчить возведенную в виде Государственного совета преграду на пути прохождения законопроектов, принятых Государственной думой.

В заседании 16 февраля вопрос о двухпалатной системе вновь был поднят теперь уже С.Ю. Витте. Он находил предложенный Оболенским 2 принцип очень важным. Предвидя, что все законодательные вопросы будут решаться в Думе, он считал вредным сохранение предусмотренного проектом принципа равноправия палат. Ведь, если Государственный совет не принимает одобренный Думой акт, то он до государя не доходит. Правило равноправия палат, которое по ошибочному мнению Витте “существует везде на Западе”, не следует заимствовать. Такая позиция определялась требованием политической целесообразности. Витте справедливо напомнил другим участникам совещания, что "государственный совет - учреждение аристократическое: крестьяне в его состав не войдут”. Им открыт доступ только в Думу. “Они и смотрят на думу так - найдем через нее доступ к царю, найдем расправу..." Без этого правила психология крестьян будет следующей. “Скажут, думали, что будет доступ, а между тем чиновники отдалили нас от государя. Таким образом, явится средостение, что крайне вредно". ${ }^{9}$

Поставив под сомнение принцип равноправия палат, Витте тем не менее не находил возможным присоединиться к предложению Оболенского 2. Он предложил несколько видоизмененную редак-

\footnotetext{
${ }^{8}$ Былое.1917. № 5-6. С.301.

${ }^{9}$ Там же. С.305-306.
} 


\section{Политика и общество 9 (117) • 2014}

цию: в тех случаях, когда Государственный совет отклоняет одобренный Думой проект, а Дума известным большинством голосов (простым или квалифицированным должно было решит совещание) пожелает, чтобы ее мнение было доведено до монарха, отказывать ей в этом не следует. Если, затем, государь император признает, что решение Думы в общих чертах правильно, то дает министрам повеление внести в Думу новый проект. Смысл предложения Витте заключался в том, чтобы доводить до сведения государя сам факт неодобрения проекта Государственным советом. Однако вряд ли этим предложением подразумевалось предоставление больших прав Думе в законодательной сфере. Только А.С. Стишинский и князья Оболенские присоединились на втором заседании к Витте. Стишинский не сомневался в том, что Государственный совет должен быть щитом верховной власти при увлечениях Думы. Вместе с тем, по его мнению, “нельзя допустить, чтобы государственный совет явился тормозом”. Чрезвычайно важно, чтобы принятые Думой положения доходили до государя ${ }^{10}$.

А.Д. Оболенский 1 отрицательно высказался о проектируемом законе. Он не оправдает ожиданий России, т.к. "им создается средостение” между императором и народом. Князь А.Д. Оболенский 2 более решительно убеждал принять предложение Витте. Он признавал нужным обязательное одобрение Государственным советом каждого закона. “Однако, когда члены думы поймут, что вследствие этого они лишаются возможности доводить до сведения" монарха свои предположения, и что сам государь не вправе их рассматривать, то это “заденет многих русских людей”. Он боялся наступления большого разочарования в обществе. Ссылаясь на то, что и в Западной Европе не все верхние палаты пользуются одинаковыми с нижними правами, он говорил о чрезвычайной важности того, чтобы император мог выслушать народных представителей ${ }^{11}$.

Однако принцип равноправия палат имел больше сторонников, он и восторжествовал. Особенно активно возражали в процессе обсуждения против нарушения принципа равноправия палат В.Н. Коковцов, М.Г. Акимов, П.Н. Дурново. Так, В.Н. Коковцов сказал: “Если будет принято мнение 2 чле-

\footnotetext{
${ }^{10}$ Там же. С.308.

${ }^{11}$ Там же. C.308-309.
}

нов, то значение государственного совета будет совершенно упразднено, или же пришлось бы допустить ту же меру и для государственной думы”. Он небезосновательно считал, что предложение о преимущественном праве Думы в области законодательства, а именно в этом суть предложенной поправки, “должно в корне подорвать всю систему”. В сущности аналогичный аргумент в пользу принципа равноправия высказал П.Н. Дурново. По его мнению, если принять предложение князя Оболенского 2, который и выступил с предложением поправки, то “через два года верхняя палата перестанет существовать" ". Подразумевалось не юридическое прекращение полномочий, а фактическая нивелировка значения верхней палаты как буфера между царем и Думой. Эти аргументы склонили в пользу большинства и Д.М. Сольского.

На заседании 16 февраля ситуация повторилась. В.Н. Коковцов справедливо отметил: то, что предлагает Витте, в сущности - то же предложение князя Оболенского. Видоизменяется оно лишь в том, что проект не представляется, а только доводится до сведения монарха. "Намечаемый путь уничтожает государственный совет и сводит к управлению страной одною палатою!” К противникам графа Витте присоединился на этот раз и Ю.А. Икскуль, также ряд других участников. По его мнению, граф Витте проектирует отдать законодательство в руки толпы. Между тем для этого дела требуется устойчивость, которую может создать Государственный совет ${ }^{13}$. К другим противникам предложения Витте относились А.А. Сабуров, В.В. Верховский. Первый высказался в целом за необходимость иметь две палаты. При одной палате получает преобладание демократия и радикализм. При двух палатах избегаются прямые коллизии между народом и монархом, в то время как при одной такие коллизии неизбежны. "Государю надо всегда соглашаться с палатою, иначе последствия будут очень нежелательны”. Второй правильно указал, что спор идет о возможности издания законов, отвергнутых Государственным советом. Именно такую возможность он считал излишней. Если же в совете образуется стена, то он предлагал монарху простой способ: выборных

\footnotetext{
12 Там же. С.302.

13 Там же. С.308.
} 
членов распустить, а чиновников убрать ${ }^{14}$. Николая II скорее всего убедили эти аргументы и он в итоге согласился с тем, как было в рассматриваемом проекте. По всей видимости, консервативность двухпалатной системы, основанной на равноправии палат, представлялась большинству участников совещания более предпочтительной для России, не имевшей, в сущности, к началу XX века традиции длительного существования сословно-представительных учреждений.

Порядок избрания Государственной думы свидетельствовал о том, что она стала рассматриваться как орган общенародного представительства, в основу которого было проложено не всеобщее избирательное право, а скорее представительство интересов.

Формирование Государственного совета было подчинено целям создания консервативной верхней палаты. Он формировался на основе смешанного принципа, сочетающего назначение и выборы. Монарх назначал половину членов верхней палаты. Вторая половина избиралась от пяти курий: 1) от православного духовенства, 2) от губернских земских собраний или от заменяющих их специальных съездов, 3) от дворянских обществ, 4) от Академии Наук и от университетов, 5) от торговли и промышленности ${ }^{15}$.

Число выборных членов Государственного совета равнялось 98. От православного духовенства избиралось шесть членов: трое из черного духовенства, трое из белого. Члены от земства избирались по одному каждым губернским земским собранием (ст.14 Учреждения Государственного совета), всего 56. Дворянские общества в губерниях и областях избирали каждое из своей среды по два выборщика; эти выборщики, съехавшись в Петербург, избирали из своей среды 18 членов Государственного совета (ст.15 Учреждения). Академия Наук в полном академическом собрании избирала из числа ординарных академиков, а совет каждого из университетов из числа ординарных профессоров - по три выборщика. Съезд этих выборщиков в Петербурге избирал из своей среды 6 членов Государственного совета (ст.16 Учреждения). В первоначальном проекте академия наук и университеты избирали по 2 выборщика. Однако на Царскосельских совещани-

\footnotetext{
14 Там же. С.309-310.

15 Учреждение Государственного совета 1906 г., ст.12. // Свод Законов Российской империи. Т.1. Ч.2. СПб., 1906.
}

ях в феврале 1906 г. по предложению Н.С. Таганцева число выборщиков было увеличено до трех. Мотив, приведенный Н.С. Таганцевым, был вполне резонным: “иначе съезд выборщиков окажется слишком малочисленным" для избрания 6 членов Государственного совета ${ }^{16}$. Представители торговли и промышленности избирались советом торговли и мануфактур, московским его отделением, комитетами торговли и мануфактур, биржевыми комитетами и купеческими управами в числе от одного до четырех. Эти представители образовывали в Петербурге съезд, который избирал шесть членов Государственного совета от торговли и шесть от промышленности (ст.17 Учреждения). Когда обсуждался состав будущего Государственного совета министр финансов И.П. Шипов высказался об имеющихся ходатайствах об избрании членов совета от банков, кредитных и ипотечных. Он поддерживал эти ходатайства и полагал, что следовало бы назначить хотя бы скромное от них представительство. Но против этого выступили Стишинский, Коковцов и Верховский, с которыми согласился император $^{17}$. Члены Государственного совета избирались на 9 лет. Каждые три года треть выборных членов выбывала в очередном порядке. В отношении членов Государственного совета по выбору от земств следует заметить, что они избирались не на 9, а на 3 года. На февральских совещаниях девятилетний срок избрания членов совета оспаривался Н.С. Таганцевым. Он спросил: “Не достаточен ли шестилетний срок для выборных членов?” Однако Витте возразил, что уменьшать девятилетний срок не надо, т.к. “чем продолжительнее срок, тем консервативнее состав избранных"18.

В ходе обсуждения проектов новых Учреждений Государственной думы и Государственного совета оживленные споры вызвали принципы формирования верхней палаты. В проекте, представленном для обсуждения, одна половина членов Государственного совета избиралась, другая половина - назначалась императором. Однако ход обсуждения выявил две различные точки зрения. Первую точку зрения открыто высказал сначала А.С. Стишинский, член Государственного совета, который отрицал необхо-

\footnotetext{
${ }^{16}$ Былое.1917. N 5-6. С.297-298.

17 Там же. С.298.

18 Там же. С.298.
} 


\section{Политика и общество 9 (117) • 2014}

димость применения принципа равенства членов по выборам и по назначению, ссылаясь на страны Западной Европы, где “иногда такого равенства и не бывает”. Во всяком случае он не считал это правило обязательным для России. Предлагая исключить слова “в равном числе", он сказал: "Правильнее, если то или другое соотношение между выбираемыми и назначаемыми членами совета будет зависеть непосредственно от вашего и.в." ${ }^{\text {. }}$

П.Н. Дурново поддержал Стишинского. По его мнению, неизвестно, “как будет складываться общественное мнение”. Поэтому он полагал, “что верховная власть не должна лишать себя права уравновешивать мнения" и считал необходимым сохранение права у монарха назначать нужное и неограниченное число членов Государственного сове$\mathrm{Ta}^{20}$. А.П. Игнатьев присоединился к этому мнению. Граф К.И. Пален его поддержал. Князь А.Д. Оболенский 2 согласился с Игнатьевым.

Вторую точку зрения активно отстаивал С.Ю. Витте, позиция которого на совещаниях в феврале 1906 года была двойственной. Граф Витте отмечал, что “только верхняя палата может спасти от необузданностей нижней. Она необходима, чтобы гарантировать консервативный строй государства, чтобы не было непосредственных коллизий с верховной властью. Назначение ее состоит в том, чтобы давать отпор всем крайним взглядам". По его мнению, “верхняя палата должна представлять из себя буфер”. Для этого существенно важно, чтобы “она заключала в себе возможно более консервативные элементы”. Витте признавал, что этим условиям “преобразуемый государственный совет удовлетворяет в полной мере”, т.к. даже в выборном составе совета “консервативный элемент будет иметь преобладающее значение". Поэтому нет оснований к увеличению числа членов по назначению. Принцип равенства числа членов по выборам и по назначению представлялся Витте справедливым. Поэтому он его отстаивал и не хотел менять ${ }^{21}$. Отход же от принципа равноправия произведет на представителей общества “дурное впечатление”.
За принцип равноправия членов по выбору и по назначению вступились члены Государственного совета Н.С. Таганцев, В.В. Верховский, В.Н. Коковцов, князь А.Д. Оболенский 1. Весьма умеренную аргументацию привел Таганцев, отмечая, что “не следует не доверять 98 членам по выбору. Нет никаких оснований предполагать, что все они образуют оппозицию"22.

Более дальновидную мысль в пользу равноправия высказал В.Н. Коковцов. Он справедливо относил вопрос о соотношении числа членов по назначению и по выборам к наиболее существенным. Однако этот вопрос, утилитарный по своему характеру, по его мнению, надо обсуждать “исключительно с точки зрения пользы” и не заимствовать все из Западной Европы. Он не видел “опасности от того или другого разделения членов по назначению и по выборам", т.к. закон мог восприять силу только после утверждения монарха. На что он и указал монарху. Вместе с тем, он считал весьма важным, чтобы Государственный совет пользовался доверием, а “искусственный подбор” такое доверие несомненно подорвет ${ }^{23}$. Николай II, выслушав сторонников обеих точек зрения, согласился оставить так, как было в проекте, т.е. поддержал принцип равноправия.

Следует отметить, что в изложенных в процессе обсуждения взглядах Витте проявился парадокс его убеждений и двойственное отношение к конституционным институтам. Инициатор конституционного по характеру манифеста 17 октября и активный проводник дальнейших государственных преобразований, он занял двойственную позицию в отношении реформы Государственной думы и Государственного совета. На заседании 14 февраля 1906 г. Витте отмечал, что “рассматриваемое преобразование еще не составляет конституции". "Преобразование это, - говорил он, - лишь аппарат в высшей степени важный, которым государь император желает управлять. Это только новое государственное устройство". По его мнению, думу и совет нельзя даже сравнивать с нижнею и верхнею палатами, а подготовленный к изданию правовой акт, регулирующий их статус “отнюдь не конституционный: никаких обязательств он не

\footnotetext{
19 Там же. С.293.

${ }^{20}$ Там же. С.294.

${ }^{21}$ Там же. С.293.
}

\footnotetext{
22 Там же. С.294.

${ }_{23}$ Там же. С.295.
} 
налагает"24. Исходя из этих убеждений, он на заседании 16 февраля отказывался принять принцип равноправия палат. Следует отметить, что Витте понимал равноправие палат как необходимый элемент конституционного порядка управления, которого, как он считал, желает В.Н. Коковцов. Между тем, по его мнению, “манифест 17 октября не устанавливает конституции”. Поэтому “незачем копировать положения конституций, по которым верхняя палата отдаляет нижнюю от монарха" ${ }^{25}$.

Таким образом, равное число членов по выборам и членов по назначению было важнейшим принципом формирования Государственного совета. Однако в отношении членов по назначению существовала норма, которая не гарантировала независимость этой категории лиц.

Учреждение предусматривало три вида членов по назначению: 1) члены, присутствующие в общем собрании Государственного совета; 2) члены присутствующие в департаментах или особых присутствиях Государственного совета; 3) члены, «не присутствующие в Совете». Верхнюю палату как законодательный орган составляли только члены по назначению первого вида. Их состав мог быть пополняем как за счет не присутствующих в Совете членов по назначению, так и за счет вновь назначаемых. При этом члены по назначению могли быть уволены только по их о том просьбе (ст.9 Учр. Гос. Совета). Это правило о несменяемости было призвано гарантировать независимость назначенных членов. Вместе с тем оно в значительной степени нейтрализовалось правительственным толкованием другой нормы. Согласно ст.11 Учреждения, «состав присутствующих в Совете членов по Высочайшему назначению, а также членов по выборам ежегодно публикуется во всеобщее сведение». Правительство истолковало это положение в том смысле, что публикация предполагала возможность ежегодного обновления состава членов Совета по назначению. Поэтому к 1 января каждого года стал публиковаться список членов по назначению, которым предстояло заседать в общем собрании Государственного совета в предстоящем году. Такая правительственная интерпретация ст.11 позволяла влиять на назначенный состав законодательной палаты и выводить из ее рядов неугодных членов Совета или тех,

\footnotetext{
24 Там же. С.295.

${ }^{25}$ Там же. С.307.
}

кто выступал против правительственной политики. Против подобного толкования не раз выступали либеральные государствоведы, однако, их голос не смог повлиять на продолжавшуюся в течение всего думского периода практику ротации.

Наряду с отмеченным толкованием существовал неписаный обычай, дополнявший ст.11. В соответствии с негласным повелением Николая II списки кандидатов в члены Государственного совета по назначению составлялись и представлялись государю по соглашению между председателем Совета министров и председателем верхней палаты. Однако, как свидетельствует Коковцов, на практике это правило никогда не исполнялось ${ }^{26}$. Председателю Совета министров (когда им был и Столыпин, а затем и Коковцов) удавалось проводить угодных кандидатов только пока он пользовался влиянием на монарха. Большей частью «назначения шли под разными негласными влияниями» или со стороны Совета объединенного дворянства, или со стороны дворцового окружения царя. Особенно способствовал формированию консервативного состава Государственного совета его председатель Акимов. Он старался провести в верхнюю палату лиц крайне правых убеждений.

Следовательно, необходимо признать, что фактически применявшийся принцип ротации членов по назначению нарушал принцип несменяемости, закрепленный в Учреждении Государственного совета.

В ходе обсуждения принципа равноправия палат был попутно затронут и вопрос о том, что такое конституция. Весьма специфическим оказалось понимание конституции у Витте, архитектора государственных преобразований. Почему же он не считал, что возникнет конституция? Потому, что, во-первых, в России нет присяги на верность устанавливаемому строю. По-видимому, присягу Витте считал необходимым элементом конституции. При этом он ссылался на мнение представителей умеренной партии 17 октября Шипова и Гучкова, которые выражали желание, “чтобы государь присягнул”. Во-вторых, государь вводит этот строй по собственной инициативе.

Взгляд Витте вызвал довольно резкую критику со стороны К.И. Палена, Ф.Г. Тернера и Н.С. Таганцева. Пален заявил: “Не подлежит никакому со-

${ }^{26}$ Коковияов В.Н. Из моего прошлого. Воспоминания. 19031919 гг. Книга вторая. М., 1992. С.6-7. 


\section{Политика и общество 9 (117) • 2014}

мнению, что Россия будет управляться по конституционному образцу”. Он считал мудрым решение сохранить три элемента конституции (монарха и две палаты). Ф.Г. Тернер отметил, ссылаясь на прусскую конституцию, что присяга не составляет обязательной принадлежности конституции. Н.С. Таганцев также высказался в том смысле, что в России конституция существует. От лица профессорской корпорации он удостоверил, что “никогда конституция не заключалась в присяге”. Отличительные ее признаки - это участие в законодательстве трех отмеченных выше факторов, которые были налицо 27.

Отсутствие четких конституционных убеждений, несомненно, помешало выработать Витте правильное отношение к преобразованиям государственного строя и построить верную тактику по отношению к либеральным партиям и их лидерам, на поддержку которых он рассчитывал и мог опереться при формировании правительства.

Двухпалатная система представительства, учрежденная и действовавшая в России, была в начале $\mathrm{XX}$ века наиболее распространенной формой организации законодательной власти. Она существовала в большинстве европейских конституционных монархий и республик: Англии, Швеции, Австрии, Дании, Бельгии, Пруссии, Франции, Швейцарии и др. Ее переняли по примеру США государства Латинской Америки, а Япония последовала европейскому опыту. При этом верхняя палата в федеративных государствах играла роль не только сдерживающего начала в отношении нижней, как это было в унитарных государствах, но и являлась «федеральной палатой» - органом представительства интересов субъектов федерации ${ }^{28}$.

Однако в России двухпалатная система с момента ее учреждения подверглась критике со стороны прессы и представителей таких политических партий, как партии «народной свободы» и РСДРП(б). В органах печати высказывалось мнение, что двухпалатная система представительства не пригодна для России, а преобразование Государственного совета не удовлетворяет демократичности общественного самосознания. В виду отсутствия в верхней па-

\footnotetext{
${ }^{27}$ Там же. С.307-308.

${ }^{28}$ Теория двухпалатной системы и практика ее применения в различных странах подробно разбиралась на страницах газеты «Право». См.: Гессен В.М. О двухпалатной системе // Право. 1906. № 19. С.1726-1738; № 31. С.2514-2525.
}

лате прогрессивных элементов, она окажется после ее формирования не отвечающей идее «истинного народовластия». Критики Государственного совета утверждали, что он не представляет достаточно ярко областных интересов, не способен по своему составу явиться ни «солидарною корпорацией», ни собранием «граждан-старейшин» ${ }^{29}$. Кадеты прямо заявили, что с Государственным советом никогда не примирятся “не только последовательные, но и самые умеренные конституционалисты" ${ }^{\text {. Наи- }}$ большую критику вызывал порядок формирования Государственного совета. Известный государствовед и конституционалист В.М. Гессен, отмечая на половину бюрократический состав верхней палаты, считал невозможным нормальное и согласное сотрудничество между Думой и Советом, т.к. слишком глубока была пропасть, которая отделяла русское общество от русской бюрократии ${ }^{31}$. Вместе с тем Государственный совет в смысле организации и периодического обновления его состава являлся учреждением достаточно либеральным в свете существовавших в других государствах верхних палат.

Западноевропейская конституционная теория и практика свидетельствовала о том, что способ формирования верхней палаты неизбежно должен строиться на ином начале, чем выборы в нижнюю палату. Преобразованный Государственный совет, как показывает сравнительно-правовой анализ, по составу и порядку формирования отличался от палаты господ в Пруссии и Австрии, где формой правления была дуалистическая монархия.

В большинстве германских государств, в том числе в Пруссии и Вюртемберге, а также в Австрии состав верхних палат был частью наследственным, частью пожизненным. Например, в Австрии палата господ состояла из совершеннолетних принцев царствующего дома; из архиепископов и некоторых епископов; из совершеннолетних представителей дворянских родов, получивших от императора наследственное право заседать в этой палате и имевших значительную недвижимую собственность в стране; наконец, из членов, пожизненно назначенных императором из числа австрийских граждан, выдающихся

\footnotetext{
29 Новейшие преобразования русского государственного строя. СПб., 1906. С.575.

${ }^{30}$ Милюков П. Год борьбы. СПб., 1907. С.287.

${ }^{31}$ Гессен В.М. Русская конституция // Гессен В.М. На рубеже. СПб., 1906. С.233-236.
} 
своими заслугами перед государством, церковью, наукой или искусством. Число таких членов, назначаемых императором, было неограниченное ${ }^{32}$.

Смешанный характер формирования верхней палаты в России был более либеральным, чем в Австрии и Пруссии, т.к. предусматривал выборность половины ее членов. Он был ближе к конституционному опыту Японии. В верхней палате (палате пэров) японского парламента заседали: 1) члены императорской фамилии; 2) все князья и маркизы; 3) графы, виконты и бароны, назначенные членами соответствующих корпораций; 4) лица, специально назначенные императором за услуги, оказанные государству, или за их знания и опытность; 5) лица, избранные по одному члену от каждого города и от каждой префектуры из среды граждан, платящих государству наибольшие суммы налогов: поземельных, промысловых или торговых. Избрание их утверждалось правительством ${ }^{33}$. Последнее положение отличало палату пэров от Государственного совета, избрание членов которого не требовало последующего утверждения.

К началу XX века конституционная практика формирования верхних палат была не только отличной от порядка выборов в нижнюю палату, но и весьма разнообразной. По своему характеру верхние палаты были: 1) палатами наследственными (палата лордов английского парламента); 2) палатами с членами частью наследственными, частью пожизненно назначенными монархом (Пруссия, Вюртемберг, Австрия); 3) палатами, все члены которых назначались монархом пожизненно (итальянский сенат); 4) палатами с членами частью наследственными, частью пожизненно назначенными монархом, частью избранными населением (палата пэров парламента Японии); 5) палатами с выборным составом (французский сенат).

Верхняя палата российского парламента имела характер, отличный от характера подобных учреждений других государств, т.к. формировалась, сочетая два принципа: принцип назначения и принцип выборности.

Следовательно, эти примеры ясно показывают, насколько во всех конституционных государствах

\footnotetext{
${ }^{32}$ Кокошкин Ф.Ф., Вышеславиев Б.П. Австро-Венгрия // Политический строй современных государств. Т.ІІ. СПб., 1906. C.141-142.

${ }^{33}$ Шрейдер Д.И. Государственный строй современной Японии // Политический строй современных государств. Т.II. СПб., 1906. С.276.
}

как монархических, так и республиканских допускалось то «средостение», на которое сетовали русские конституционалисты ${ }^{34}$.

С позиций политической целесообразности ЦК кадетов на заседании 5 марта принял решение, которым санкционировалось участие отдельных членов партии в выборах в Государственный совет и рекомендовалось им стать его членами. Это решение было направлено на формирование в верхней палате группы единомышленников, которая будет способствовать проведению либеральных законопроектов, принятых Думой ${ }^{35}$. Отрицательное отношение к Государственному совету было и у выборщиков от академии и университетов, которые приняли по этому поводу специальную декларацию. Выборщики заявили, что на Государственный совет никто не захочет смотреть, как на вторую палату; что отношение прогрессивных элементов к совету может быть только “оппозиционное” и что данная группа сознательно идет в это учреждение исключительно для борьбы против него, для поддержки в совете политики Думы и для парализации “всяких попыток правительства ограничить права думы или помимо её управлять страной”з6.

Отрицательное отношение либералов и прогрессивной общественности к порядку формирования Государственного совета было конкретным проявлением неприятия верхней палаты как таковой. Политические взгляды кадетов на верхнюю палату способствовали формированию негативного общественного мнения в стране о факте существования Государственного совета. Поэтому именно в Государственной думе представители либеральных и социалистических партий видели орган народного представительства и отказывались признать представительный характер за Государственным советом.

Политическая судьба монархического бикамерализма - первого в конституционной истории России была значимой как конституционный опыт взаимодействия законодательных палат на общенациональном уровне, однако имела плачевное завершение и не оказалась востребованной для совершенствования государственного строя.

\footnotetext{
34 Новейшие преобразования русского государственного строя. СПб., 1906. С.579.

${ }^{35}$ Шелохаев В.В. Либеральная модель переустройства России. М., 1996. С.53.

${ }^{36}$ Милюков П. Год борьбы. СПб., 1907. С.291.
} 


\section{Политика и общество 9 (117) • 2014}

\section{Библиография:}

1. Булаков О.Н. Бикамеральная структура парламента (практика и проблемы законотворчества) // Конституционное и муниципальное право. 2006. № 9. С. 9-12.

2. Юртаева Е.А. Государственный совет в России. 1906-1917 гг. М.: Едиториал УРСС, 2011.

3. Юртаева Е.А. Государственный Совет в России (1906-1917 гг.) // Государство и право. 1996. №4. С. $145-152$.

4. Hosking G.A. Russian constitutional experiment: Government and Duma, 1907-1914. Cambridge, 1973.

5. Покровский М.Н. Земский собор и парламент // Конституционное государство. Сб. статей. СПб., 1905. С.431-459.

6. Гессен В.М. Основы конституционного права. Изд. 2-е. Петроград, 1918.

7. Лазаревский Н.И. Лекции по русскому государственному праву. Т.1. СПб., 1908.

8. Царскосельские совещания. Протоколы секретного совещания в феврале 1906 года под председательством бывшего императора по выработке Учреждений Государственной думы и Государственного совета. (14 и 16 февраля 1906 г.) // Былое.1917. № 5-6.

9. Учреждение Государственного совета 1906 г. // Свод Законов Российской империи. Т.1. Ч.2. СПб., 1906.

10. Коковцов В.Н. Из моего прошлого. Воспоминания. 1903-1919 гг. Книга вторая. М., 1992.

11. Гессен В.М. О двухпалатной системе // Право. 1906. № 19. С.1726-1738; № 31. С.2514-2525.

12. Новейшие преобразования русского государственного строя. СПб., 1906.

13. Милюков П. Год борьбы. СПб., 1907.

14. Гессен В.М. Русская конституция // Гессен В.М. На рубеже. СПб., 1906.

15. Кокошкин Ф.Ф., Вышеславцев Б.П. Австро-Венгрия // Политический строй современных государств. Т.ІІ. СПб., 1906.

16. Шрейдер Д.И. Государственный строй современной Японии // Политический строй современных государств. Т.ІІ. СПб., 1906.

17. Шелохаев В.В. Либеральная модель переустройства России. М., 1996.

18. Селунская Н.Б. Механизм формирования политических представлений выборщиков в России в начале XX в. // NB: Проблемы общества и политики. - 2013. - 5. - C. 190-220. DOI: 10.7256/2306-0158.2013.5.654. URL: http://www.enotabene.ru/pr/article_654.html

19. Алейников А.В. Системные конфликты в России: концептуальные основания анализа. Статья II. // NB: Проблемы общества и политики. - 2013. - 8. - C. 1-47. DOI: 10.7256/2306-0158.2013.8.5109. URL: http://www.e-notabene.ru/pr/ article_5109.html

20. Кодан С.В. Система законодательства в России: формирование, развитие, становление (IX - начало XX вв.) // NB: Проблемы общества и политики. - 2013. - 4. - C. 239-293. DOI: 10.7256/2306-0158.2013.4.436. URL: http://www.enotabene.ru/pr/article_436.html

21. С. В. Кодан. Попытки создания Основных законов Российской империи в политике, идеологии и юридической практике Российского государства (XVIII - начало XIX вв.) // Право и политика. - 2012. - № 3. - C. $104-107$.

22. С.В. Кодан. Презумпции знания закона в российском праве: формирование, закрепление, обеспечение (XVI - начало ХХ вв.) // Право и политика. - 2012. - № 11. - С. 104-107.

23. Кодан С.В. Политико-юридический подход в исследовании государственно-правового развития России (XIX - начало XX вв.) // NB: Проблемы общества и политики. - 2012. - № 2. - C.88-117. DOI: 10.7256/2306-0158.2012.2.177. URL: http://e-notabene.ru/pr/article_177.html

24. Кодан С.В., Февралёв С.А. Местное право национальных регионов Российской Империи: истоки, место в политике и иделогии, юридическая природа (вторая половина XVII-начало XX вв.) // NB: Вопросы права и политики. -2013. - № 2. - C.74-154. DOI: 10.7256/2305-9699.2013.2.464. URL: http://e-notabene.ru/lr/article_464.html

25. Кодан С.В. Сословное законодательство в политике российской верховной власти (1800-1850-е гг.) // NB: Вопросы права и политики. - 2012. - № 2. - C.117-145. DOI: 10.7256/2305-9699.2012.2.152. URL: http://e-notabene.ru/lr/ article 152.html

26. Кодан С.В. Создание Основных законов Российской империи в деятельности Комиссии составления законов (1800-1820-е гг.) // NB: Вопросы права и политики. - 2012. - № 3. - C.149-175. DOI: 10.7256/2305-9699.2012.3.167. URL: http://e-notabene.ru/lr/article_167.html

27. Кодан С.В. Система законодательства В России: формирование, развитие, становление (IX - начало XX вв.) // NB: Проблемы общества и политики. - 2013. - № 4. - C.239-293. DOI: 10.7256/2306-0158.2013.4.436. URL: http://enotabene.ru/pr/article_436.html

28. Кодан С.В., Владимирова Г.Е. Закрепление в Своде Основных государственных законов Российской империи 1832-1892 гг. издания правового положения членов императорского дома // NB: Вопросы права и политики. - 2014. - № 5. - C.38-68. DOI: 10.7256/2305-9699.2014.5.11587. URL: http://e-notabene.ru/lr/article_11587.html

29. Т. М. Баженова, С. В. Кодан. К 175-летию издания Свода законов Российской империи. Свод законов Российской империи в правовом развитии России. // Право и политика. - 2008. - № 1. 
30. Кодан С.В. Зарождение источниковедения истории государства и права в отечественной исторической науке и правоведении (XVIII - начало XIX вв.) // NB: Вопросы права и политики. - 2014. - № 7. - C.48-65. DOI: 10.7256/23059699.2014.7.12062. URL: http://e-notabene.ru/lr/article 12062.htm

31. Селунская Н.Б. Механизм формирования политических представлений выборщиков в России в начале XX в. // NB: Проблемы общества и политики. - 2013. - 5. - C. 190 - 220. DOI: 10.7256/2306-0158.2013.5.654. URL: http://www.enotabene.ru/pr/article_654.html

32. Кодан С.В. Система законодательства в России: формирование, развитие, становление (IX - начало XX вв.) // NB: Проблемы общества и политики. - 2013. - 4. - С. 239 - 293. DOI: 10.7256/2306-0158.2013.4.436. URL: http://www.enotabene.ru/pr/article_436.html

33. Щупленков О.В., Щупленков Н.О. Политика переселения населения в России начала XX века - методология вопроса // Урбанистика. - 2013. - 1. - C. 31 - 72. DOI: 10.7256/2310-8673.2013.1.10383. URL: http://www.e-notabene. $\mathrm{ru} / \mathrm{urb} /$ article_10383.html

34. Красняков Н.И. Модернизация имперских институтов власти в России XVIII - начала XIX вв. // NB: Вопросы права и политики. - 2013. - 10. - C. 149 - 174. DOI: 10.7256/2305-9699.2013.10.9767. URL: http://www.e-notabene.ru/lr/ article_9767.html

\section{References (transliterated):}

1. Bulakov O.N. Bikameral'naya struktura parlamenta (praktika i problemy zakonotvorchestva) // Konstitutsionnoe i munitsipal'noe pravo. 2006. № 9. S. 9-12.

2. Yurtaeva E.A. Gosudarstvennyi sovet v Rossii. 1906-1917 gg. M.: Editorial URSS, 2011.

3. Yurtaeva E.A. Gosudarstvennyi Sovet v Rossii (1906-1917 gg.) // Gosudarstvo i pravo. 1996. №4. S. $145-152$.

4. Hosking G.A. Russian constitutional experiment: Government and Duma, 1907-1914. Cambridge, 1973.

5. Pokrovskii M.N. Zemskii sobor i parlament // Konstitutsionnoe gosudarstvo. Sb. statei. SPb., 1905. S.431-459.

6. Gessen V.M. Osnovy konstitutsionnogo prava. Izd. 2-e. Petrograd, 1918.

7. Lazarevskii N.I. Lektsii po russkomu gosudarstvennomu pravu. T.1. SPb., 1908.

8. Kokovtsov V.N. Iz moego proshlogo. Vospominaniya. 1903-1919 gg. Kniga vtoraya. M., 1992.

9. Gessen V.M. O dvukhpalatnoi sisteme // Pravo. 1906. № 19. S.1726-1738; № 31. S.2514-2525.

10. Milyukov P. God bor'by. SPb., 1907.

11. Gessen V.M. Russkaya konstitutsiya // Gessen V.M. Na rubezhe. SPb., 1906.

12. Kokoshkin F.F., Vysheslavtsev B.P. Avstro-Vengriya // Politicheskii stroi sovremennykh gosudarstv. T.II. SPb., 1906.

13. Shreider D.I. Gosudarstvennyi stroi sovremennoi Yaponii // Politicheskii stroi sovremennykh gosudarstv. T.II. SPb., 1906.

14. Shelokhaev V.V. Liberal'naya model' pereustroistva Rossii. M., 1996.

15. Selunskaya N.B. Mekhanizm formirovaniya politicheskikh predstavlenii vyborshchikov v Rossii v nachale KhKh v. // NB: Problemy obshchestva i politiki. - 2013. - 5. - C. 190-220. DOI: 10.7256/2306-0158.2013.5.654. URL: http://www.e-notabene.ru/pr/article_654.html

16. Aleinikov A.V. Sistemnye konflikty v Rossii: kontseptual'nye osnovaniya analiza. Stat'ya II. // NB: Problemy obshchestva i politiki. - 2013. - 8. - C. 1-47. DOI: 10.7256/2306-0158.2013.8.5109. URL: http://www.e-notabene.ru/pr/article_5109.html

17. Kodan S.V. Sistema zakonodatel'stva v Rossii: formirovanie, razvitie, stanovlenie (IX - nachalo XX vv.) // NB: Problemy obshchestva i politiki. - 2013. - 4. - C. 239-293. DOI: 10.7256/2306-0158.2013.4.436. URL: http://www.e-notabene. $\mathrm{ru} / \mathrm{pr} / \mathrm{article}$ 4 $436 . \mathrm{html}$

18. S. V. Kodan. Popytki sozdaniya Osnovnykh zakonov Rossiiskoi imperii v politike, ideologii i yuridicheskoi praktike Rossiiskogo gosudarstva (XVIII - nachalo XIX vv.) // Pravo i politika. - 2012. - № 3. - S. 104-107.

19. S.V. Kodan. Prezumptsii znaniya zakona v rossiiskom prave: formirovanie, zakreplenie, obespechenie (XVI - nachalo XX vv.) // Pravo i politika. - 2012. - № 11. - S. 104-107.

20. Kodan S.V. Politiko-yuridicheskii podkhod v issledovanii gosudarstvenno-pravovogo razvitiya Rossii (XIX - nachalo XX vv.) // NB: Problemy obshchestva i politiki. - 2012. - № 2. - S.88-117. DOI: 10.7256/2306-0158.2012.2.177. URL: http://e-notabene.ru/pr/article_177.html

21. Kodan S.V., Fevralev S.A. Mestnoe pravo natsional' 'nykh regionov Rossiiskoi Imperii: istoki, mesto v politike i idelogii, yuridicheskaya priroda (vtoraya polovina XVII-nachalo XX vv.) // NB: Voprosy prava i politiki. - 2013. - № 2. - S.74154. DOI: $10.7256 / 2305-9699.2013 .2 .464$. URL: http://e-notabene.ru/lr/article_464.html

22. Kodan S.V. Soslovnoe zakonodatel'stvo v politike rossiiskoi verkhovnoi vlasti (1800-1850-e gg.) // NB: Voprosy prava i politiki. - 2012. - № 2. - S.117-145. DOI: 10.7256/2305-9699.2012.2.152. URL: http://e-notabene.ru/lr/article_152.html

23. Kodan S.V. Sozdanie Osnovnykh zakonov Rossiiskoi imperii v deyatel'nosti Komissii sostavleniya zakonov (1800-1820-e gg.) // NB: Voprosy prava i politiki. - 2012. - № 3. - S.149-175. DOI: 10.7256/2305-9699.2012.3.167. URL: http://e-notabene.ru/lr/article_167.html 


\section{Политика и общество $9(117) \cdot 2014$}

24. Kodan S.V. Sistema zakonodatel'sstva v Rossii: formirovanie, razvitie, stanovlenie (IX - nachalo XX vv.) // NB: Problemy obshchestva i politiki. - 2013. - № 4. - S.239-293. DOI: 10.7256/2306-0158.2013.4.436. URL: http://e-notabene.ru/ pr/article_436.html

25. Kodan S.V., Vladimirova G.E. Zakreplenie v Svode Osnovnykh gosudarstvennykh zakonov Rossiiskoi imperii 18321892 gg. izdaniya pravovogo polozheniya chlenov imperatorskogo doma // NB: Voprosy prava i politiki. - 2014. - № 5. - S.38-68. DOI: 10.7256/2305-9699.2014.5.11587. URL: http://e-notabene.ru/lr/article 11587.html

26. T. M. Bazhenova, S. V. Kodan. K 175-letiyu izdaniya Svoda zakonov Rossiiskoi imperii. Svod zakonov Rossiiskoi imperii v pravovom razvitii Rossii. // Pravo i politika. - 2008. - № 1.

27. Kodan S.V. Zarozhdenie istochnikovedeniya istorii gosudarstva i prava $\mathrm{v}$ otechestvennoi istoricheskoi nauke $\mathrm{i}$ pravovedenii (XVIII - nachalo XIX vv.) // NB: Voprosy prava i politiki. - 2014. - № 7. - S.48-65. DOI: 10.7256/23059699.2014.7.12062. URL: http://e-notabene.ru/lr/article_12062.htm

28. Selunskaya N.B. Mekhanizm formirovaniya politicheskikh predstavlenii vyborshchikov v Rossii v nachale KhKh v. // NB: Problemy obshchestva i politiki. - 2013. - 5. - C. 190 - 220. DOI: 10.7256/2306-0158.2013.5.654. URL: http://www.enotabene.ru/pr/article_654.html

29. Kodan S.V. Sistema zakonodatel' 'stva v Rossii: formirovanie, razvitie, stanovlenie (IX - nachalo XX vv.) // NB: Problemy obshchestva i politiki. - 2013. - 4. - C. 239 - 293. DOI: 10.7256/2306-0158.2013.4.436. URL: http://www.e-notabene.ru/ pr/article_436.html

30. Shchuplenkov O.V., Shchuplenkov N.O. Politika pereseleniya naseleniya v Rossii nachala KhKh veka - metodologiya voprosa // Urbanistika. - 2013. - 1. - C. 31 - 72. DOI: 10.7256/2310-8673.2013.1.10383. URL: http://www.e-notabene. ru/urb/article_10383.html

31. Krasnyakov N.I. Modernizatsiya imperskikh institutov vlasti v Rossii XVIII - nachala XIX vv. // NB: Voprosy prava i politiki. - 2013. - 10. - C. 149 - 174. DOI: 10.7256/2305-9699.2013.10.9767. URL: http://www.e-notabene.ru/lr/ article_9767.html 